\title{
Radical democracy and the rule of law: reflections on J. Habermas' legal philosophy
}

I met Jürgen Habermas thirty years ago at around the time when he completed his Between Facts and Norms. In that book, Habermas defended a provocative thesis-the view that "in the age of a completely secularised politics, the rule of law cannot be had without radical democracy." ${ }^{1}$ I believe this view to be essentially correct and, with hindsight, would like to explore some of its key intellectual motivations that explain why this view remains relevant and provocative in contemporary discourse-but also add a challenge.

Two mutually antagonistic conceptions of the rule of law continue to dominate contemporary debate. The first of these associates the rule of law with limited government and the function of providing a secure framework for the spontaneous order of free markets. This conception prioritises economic liberties and emphasizes the importance of rules fixed in advance that allow private actors to foresee with certainty how public authority will use its coercive power in given circumstances. The ground rules of private law-property and freedom of contract-are often thought to meet this requirement par excellence and to epitomize the pure form of law. The second of these two conceptions, by contrast, sees the rule of law as an entirely political construct only. Suspicious of judicial supremacy in a society riven by deep moral dissensus, this view argues that no distinction between an impersonal point of view established in a liberal democracy's institutions and laws, on the one hand, and the controversial views of the good and of social justice, on the other, can ever be drawn. Accordingly, each version of the rule of law-and there can only be plural versions, on this view-is seen either as yet another ideological project or as purely contextual. ${ }^{2}$

However, in contrast to these two conceptions, Habermas argued for a third view that sought to tie the rule of law not to some trans-historical content but to a situated emancipatory democratic practice. Framed by close reference to Max Weber's categories, Habermas' aim was to understand how the "paradoxical emergence of legitimacy out of legality" ${ }^{3}$ is possible.

The emergence of legitimacy out of legality may appear paradoxical for this reason: for, on the one hand, as democratically responsible citizens we depend on a coercive legal order in order to achieve the goods of social cooperation and solidarity among strangers. Without law, there simply would be no hope of achieving the coordination necessary for such goods in highly complex modern societies, which "rely on the decentralised decisions of self-interested individuals in morally neutralised spheres of action." ${ }^{4}$ From our decentralised vantage points as the addressees of law, legal ordering has the decisive advantage of releasing us from the burdens of reciprocal moral justification: the right to private autonomy "extends as far as the legal subject does not have to give others ... publicly acceptable reasons for her action plans" and thus allows the addressees of a given legal order "to drop out of communicative action." ${ }^{5}$ In this way, legal ordering responds to cognitive indeterminacy in complex societies as much as it compensates motivational uncertainty. Without the availability of

\footnotetext{
* UCL Faculty of Laws.

1 J Habermas, Between Facts and Norms (Polity: 1996), xlii [Faktizität und Geltung (Ffm: Suhrkamp: 1992].

${ }^{2}$ For a discussion, cf. Mark Tushnet, Critical Legal Studies and the Rule of Law (SSRN: 2018).

${ }^{3}$ Ibid., at 83.

${ }^{4}$ Ibid.

${ }^{5}$ Ibid., at 120 (emphasis in the original).
} 
a coercive legal system that ensures coordination, citizens, even those who are morally motivated, could only fall back on pure aspiration that has no practical or institutional expression.

On the other hand, however, the imposition of legal coercion must meet the stringent requirements of legitimacy and thus always poses a problem of moral justification through some form of nondominated discourse. "Modern law," as Habermas explains, "displaces normative expectations from morally unburdened individuals onto the laws that secure the compatibility of liberties." ${ }^{6}$ Yet if these "normative expectations" include first and foremost the recognition of the commanding logic of reciprocity and communicative reason, as Habermas says they must, then this displacement from the morally unburdened individuals opens up the morality of law itself. Democratically responsible citizens must be able to comply with the directives of a coercive legal order also based on moral motives. Legal coercion must always invite but never destroy those moral motives citizens may have for obeying the law. For it is only through a legal system which, in last resort, is acceptable to all who are affected that social solidarity can spread to the multifarious, morally neutralised spheres of action in modern, differentiated and decentralised economic societies and that law can serve as a "transmission-belt" ${ }^{7}$ of solidarity and social integration.

Habermas found the solution to the "paradox" of achieving legitimacy through legality in the very idea of a democratic procedure itself. Whereas the self-understanding of legalistic thinkers of the past has always turned around the proper relation of law to morality, Habermas, by contrast, has shifted the focus onto the relation between law and politics. For we simply can no longer assume that, when moral rules and principles are applied in court, the judges can escape the political conflicts of a pluralistic society. Where citizens hold mutually antagonistic, but often reasonable, views about social justice, resolution of those conflicts cannot be pictured as the integration of morality into law by judicial acts of pure practical reason. "The idea of self-legislation by citizens," Habermas accordingly insisted, always "requires that those subject to law as its addressees can at the same time understand themselves as authors of the law." ${ }^{8}$ In order to eliminate "the paternalism of the 'rule of law' characteristic of heteronomy," we must take as our point of departure the idea that "[i]t is only participation in the practice of politically autonomous law making that makes it possible for the addressees of law to have a correct understanding of the legal order as created by themselves. ${ }^{\prime 9}$ However, in order for this practice to truly count as politically autonomous, citizens must already be able to rely on law to be able to "institutionalise" - that is to say, to simultaneously enable and morally constrain - the kind of discursive politics that eventually produces legitimacy. In this sense, legitimate law and radical democracy are not only co-original but also always cooriginating in an ongoing reformist process in which citizens apply the discourse-principle to the legal form.

However, while Habermas thus clearly rejects a court-centric legalism, he also did not entirely align himself with the various positions which today fly under the flag of political (or popular) constitutionalism and that do away with judicial review. As scholars such as Michelman and Tushnet have noted, the whole point of creating court-like institutions is to create a procedure that can resolve controversy over what the correct specification of constitutional meaning is. ${ }^{10}$ And the fact

\footnotetext{
${ }^{6}$ Ibid., at 83 (my emphasis).

${ }^{7}$ Ibid., at 118 and 83 .

${ }^{8}$ Ibid., 120 (emphasis in the original).

${ }^{9}$ Ibid., at 121 (emphasis in the original).

${ }^{10}$ Frank Michelman, Legitimacy, The Social Turn and Constitutional Review: What Political Liberalism Suggests, in: KritV | CritQ | Rcrit, 98 (2015) 3, pp. 183-205; Mark Tushnet, Weak Courts, Strong Rights (Princeton UP: 2008), at 71-5.
} 
that, in following this procedure in good faith, you may lose the argument-because your constitutional interpretation does not prevail-is no reason yet to withhold allegiance to the constitution as procedure. This is so as long as you can reasonably maintain belief in the possibility of persuading others-ultimately the court-eventually to endorse your views about constitutional meaning in successive future rounds of debate. In this proceduralizing move there lies an important family-resemblance between the views of Michelman, Tushnet and Habermas.

The "proceduralist paradigm of law," which Habermas accordingly proposed, aimed at preservingagainst the empirical backdrop of the ambiguities of the modern administrative and social welfare state-an important role for courts and for judicial review. In particular, it does so when it comes to striking a fair balance between the autonomy-protective function of law, on the one hand, and policy in the social sphere, on the other. This paradigm is proceduralist in the sense that "it merely states the conditions under which ... citizens can reach an understanding with one another about what their problems are and how they are to be resolved." Law is a matter not only of "the selfunderstanding of elites" but, in final resort, of "all participants;" and the new paradigm constantly exposes itself to discussion in the wider public-but always "under its own [discourse-theoretical] conditions" ${ }^{11}$ of non-domination. For Habermas believed that "politics is responsible for problems that concern society as a whole." To carry this burden, politics cannot merely be a matter of aggregating exogenous preferences but must be deliberative. This means that "it must be possible to interpret collectively binding decisions as a realization of rights such that the structures of recognition built into communicative action are transferred, via the medium of law, from the level of simple interactions [in the lifeworld] to the abstract and anonymous relationships among strangers." ${ }^{12}$ However, at the same time, this kind of lifeworld-originating politics is under constant threat of distortion whenever "the administrative system becomes independent of communicatively generated power."13 Given this threat, the proceduralist paradigm, then, aimed at showing how judicial review can serve the needs of true politics by making it deliberative without, however, itself colonialising politics by destroying the citizens' moral motives for obeying the law.

Habermas' proceduralism invites the question of who is the "self" of the self-legislation by citizens. On the one hand, Habermas rightly (as I believe) insisted that the idea of popular sovereignty must be, as he puts it, "desubstantialized." There is no pre-legal or pre-political demos but there are only the manifold "subjectless forms of communication" 14 that allow "reasons to float freely"15 in and across a decentered society where the political system is "neither peak nor center." But, on the other hand, and based on his juxtaposition between system and lifeworld, Habermas argued that in order to achieve, in contemporary conditions, the kind of democratic accountability which true politics demands the public sphere can only beleaguer, or lay siege to, the, respectively, political, legal, and administrative systems of society. "Communicative power," he writes, "is exercised in the manner of a siege. It influences the premises of judgment and decision making in the political system without intending to conquer the system itself." ${ }^{16}$ It is here where questions as to the normative and empirical adequacy of this picture arise.

\footnotetext{
${ }^{11}$ Ibid., at 445.

12 Ibid., at 385 .

${ }^{13}$ Ibid., at 386.

${ }^{14} \mathrm{~J}$ Habermas, Three Normative Models of Democracy, in: S Benhabib (ed.) Democracy and

Difference. Contesting the Boundaries of the Political (Princeton: 1996), 21-30, at 29.

${ }^{15} \mathrm{~J}$ Habermas, Postscript, in Between Facts and Norms, at 448.

${ }^{16} \mathrm{~J}$ Habermas, Popular Sovereignty as Procedure, in id., at $486 \mathrm{f}$.
} 
To my mind, Habermas' juxtaposition risks seriously downplaying not only the deep professional expertise but also the deliberative processes-established and emergent-embedded in what he considers as "system" as opposed to undistorted lifeworld-politics. As critics have noted, Habermas' argument has the problematic consequence of making radical democracy foreign to the institutions it beleaguers and, indeed, as one must add, to the crucial modes of governance in the transnational context. ${ }^{17}$ Yet under today's conditions of pervasive moral dissensus and pragmatic uncertainty there is not one single, privileged locus of true politics at the commanding head end of the discursive Habermasian "transmission-belt." Much of contemporary scholarship accordingly investigates how, foregoing judicial finality, courts exert a forum-creative role by entering into a non-hierarchical dialogue with other, non-court actors. These may be legislatures and other branches of government; emergent collaborative modes of governance ${ }^{18}$ in the exemplary contexts of human rights, ${ }^{19}$ environmental protection, ${ }^{20}$ the European social market, ${ }^{21}$ free trade agreements ${ }^{22}$ etc.; and also, at the same time, social movements and other actors and stakeholders in civil society and the wider public. Almost by definition, these departmentalised forums of deliberation straddle the systemlifeworld divide-and yet they all participate in, and contribute to, constitutional interpretation. Constitutional compliance becomes a process of elaborating, contextualising, revising and deepening constitutional meaning, almost in Socratic fashion, as experience accumulates-and less of sporadic siege by an exceptionalised public sphere as the place of true politics.

My point here is-emphatically-not that complexity forces us to lower our normative (and regulatory) ambition. To the contrary, the project of institutionally deepening democracy may well be the best hope we have for preserving democracy where the ability of politics to exert collective responsibility for problems that concern society as a whole is often thought to be in serious jeopardy. At least, this is what I have come to think what Habermas, too, thinks or must have meant, looking back on his contribution from the vantage point of a body of thought that is both inspired by his and critical of it.

\footnotetext{
17 Joshua Cohen, Reflections on Habermas on Democracy, in: id., The Arc of the Moral Universe and Other Essays, 260-96, at 290 (Harvard UP: 2010).

${ }^{18}$ Charles F. Sabel and William H. Simon, Destabilization Rights: How Public Law Litigation Succeeds, 117 Harvard Law Review 1016 (2003-2004); cf. also Mark Tushnet, The Inadequacy of Judicial Enforcement of Constitutional Rights Provisions to Rectify Economic Inequality, and the Inevitability of the Attempt, Harvard Public Law Working Paper No. 18-25; Richard H. Fallon, Judicial Supremacy, Departmentalism, and the Rule of Law in a Populist Age, 96 Texas Law Review, 487-553 (2018).

${ }^{19}$ Gráinne de Burca, Human Rights Experimentalism, in: 111 American Journal of International Law 277-316 (2017).

${ }^{20}$ Joanne Scott, The Geographical Scope of the EU's Climate Responsibilities, in: Volume 17 (2015) Cambridge Yearbook of European Legal Studies.

${ }^{21}$ Oliver Gerstenberg, Euroconstitutionalism and Its Discontents (OUP: 2018).

${ }^{22}$ Charles F. Sabel, Sovereignty and Complex Interdependence: Some Surprising Indications of their Compatibility, in: Ideas that Matter: Democracy, Justice, Rights, edited by Annabelle Lever and Debra Satz, Oxford University Press, 2019.
} 